\title{
Impact of nitrogen topdressing on the quality and quantity parameters of yield and grain protein of wheat (Triticum aestivum L.)
}

\author{
Adnan ESER \\ Crop Production Institute, Szent István University, 2100 Gödöllő, Páter Károly utca 1. ; \\ E-mail: adnaneser@hotmail.com
}

Keywords: grain protein, gluten, winter wheat, moisture, nitrogen

\section{Introduction}

There is more land planted to wheat in the world than any other crop. It provides 20 percent of the world's caloric consumption and for the world's poorest 50 percent, 20 percent of their protein consumption too (Washington Wheat Facts 2015/2016). The total global wheat output exceeded 749.3 million tonnes in 2016, according to FAOSTAT data (FAOSTAT 2017). The goal of wheat production is twofold; provide quantity and quality. Milling and baking quality of wheat are mainly determined by the genetic basis (Kassai 1991; Kassai 1994), however, it can be influenced by management techniques (Grimwade et al., 1996; Pollhamer 1981; Pepó 2010; Vida et al., 1996; Kassai et al., 2015; Kassai et al., 2016; Jolánkai et al., 2016).

\section{Materials and methods}

For long-term field trials high milling and baking quality winter wheat varieties $\mathrm{Mv}$ Karéj, Mv Nádor, Mv Krajcár, Mv Kolompos and Alföld (Triticum aestivum L.) were sown. The small plots trial with four replications run at Nagygombos, experimental field Crop Production Institute of Szent Istvan University, Hungary. The size of each plot is 10 $\mathrm{m}^{2}$. Soil type of the experimental field is chernozem (calciustoll). Annual precipitation of the experimental site belongs to the 550-600 mm belt of the Northern edges of the Hungarian Great Plain. Identical agronomic treatment applied to each plot. Supply of N fertiliser planned for single and divided doses. Applications of $\mathrm{N}$ topdressing will be done by 6 levels: $0,80,120,160 \mathrm{~kg} / \mathrm{ha} \mathrm{N}$ in single supply and $80+40,120+40 \mathrm{~kg} / \mathrm{ha} \mathrm{N}$ in two applications. After harvest, samples were analysed in the laboratory of Crop Production Institute of Szent Istvan University in the regard of hectolitre mass $(\mathrm{kg} / \mathrm{hl})$, thousand grain weight $(\mathrm{g})$, baking quality, protein $(\%)$, moisture $(\%)$ and gluten $(\%)$.

\section{Results and discussion}

Experimental results showed that ascending doses of $\mathrm{N}$ application caused in yield increase regarding all varieties. Tested wheat grain samples protein and gluten content indicate that $\mathrm{N}$ supply has high effect on examined varieties. Specially $80+40 \mathrm{~kg} / \mathrm{h}$ and $120+40 \mathrm{~kg} / \mathrm{h}$ divided applications were remarkable on 2016 trial Figure 1 data of protein performance in 2016. Figure 2 data of gluten performance in 2016 but on the 2017 trials could not monitor the same effect on splited application of $\mathrm{N}$ supply Figure 3 data of protein performance in 2017. Figure 4 data of gluten performance in 2017 

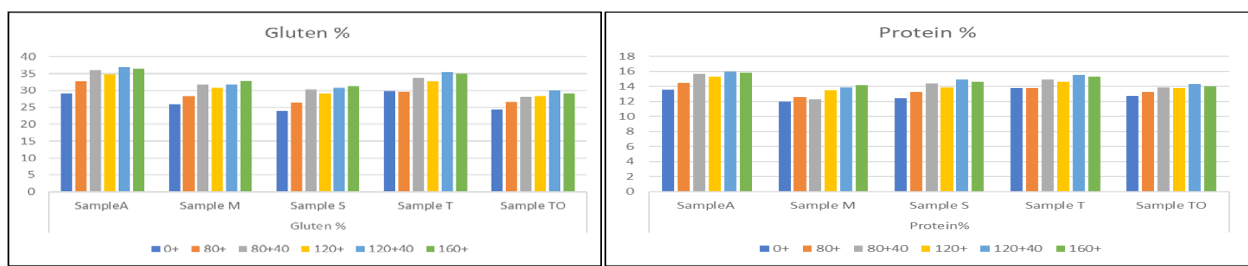

Figure 1: Impcat of $N$ topdressing applications on wheat grain protein, 2016

Figure 2: Impact of $N$ topdressing applications on wheat

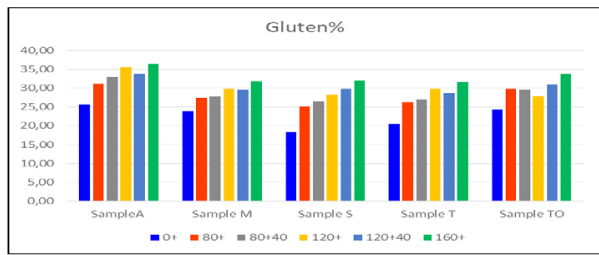
grain protein, 2016

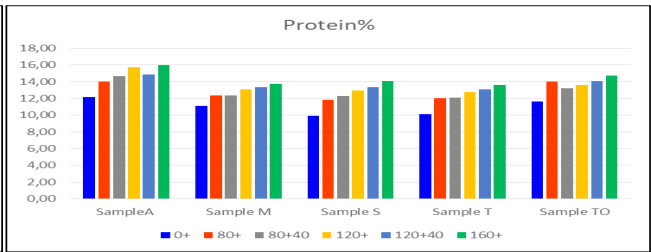

Figure 3: Impcat of $N$ topdressing applications on wheat grain protein, 2017

Figure 4: Impcat of $N$ topdressing applications on wheat

\section{Conclusions}

The outcome of the experiment highlight that increasing levels of $\mathrm{N}$ supplement proved to have a positive effect on the grain protein amount and crop yield of winter wheat varieties. No significant effect has been found on moisture content

\section{Acknowledgement}

I am indebted regarding the all supports and efforts of my supervisor, Prof. Jolánkai Márton and financial support of the Hungarian Government managed by Tempus

\section{References}

FAO (2017): Food and Agriculture Organization of the United Nations, Land Resources. FAOSTATS-Crops. http://faostat.fao.org/site/567/default.aspx\#ancor.

Grimwade B, Tatham AS, Freedman RB, Shewry PR, Napier JA. (1996): Comparison of the expression patterns of wheat gluten proteins and proteins involved in the secretory pathway in developing caryopses of wheat. Plant Molecular Biology 30, 1067-1073. DOI: 10.1007/BF00020817

Kassai M.K. (1991): Recent paleobotanical research in Hungary. In: New Light on Early Farming : Recent Developments in Palaeoethnobotany /Ed: Jane, M RENFREW/. Edinburgh, UK. Edinburgh University Press. 277-279 pp.

Kassai M.K. (1994): Production of leguminous crops in Hungary. Grain Legumes Paris. 5. 24-25 pp.

Kassai M.K., Tarnawa Á., Nyárai H.F., Pósa B. , Jolánkai M. (2015): The effect of crop species and N fertilization on soil organic matter. Columella 2. 2. 23-28 pp.

Kassai M.K., Tarnawa Á., Nyárai H.F., Pósa B., Jolánkai M. (2016): Effect of carbon sequestration of wheat (Triticum aestivum L.) varieties on soil organic matter. Georgikon for Agriculture. 20. 1. 20-26 pp.

Jolánkai M., Tarnawa Á., Horváth Cs., Nyárai H.F., Kassai K. (2016): Impact of climatic factors on quantity and quality of grain crops. Időjárás. 120. 1. 73.84 pp

Pepó P. (2010): Adaptive capacity of wheat (Triticum aestivum L.) and maize (Zea mays L.) crop models to ecological conditions. Növénytermelés. 59. Suppl. 325-328.

Pollhamer. E. (1981): A búza és a liszt minősége. (Quality of wheat and flour). Mezőgazdasági Kiadó. Budapest.

Peter R. Shewry, Nigel G. Halford; Cereal seed storage proteins: structures, properties and role in grain utilization, Journal of Experimental Botany, Volume 53, Issue 370, 15 April 2002, Pages 947-958, https:// doi.org/10.1093/jexbot/53.370.947

Vida Gy., Bedő Z., Jolánkai M. (1996): Agronómiai kezeléskombinációk őszi búzafajták sütőipari minőségére gyakorolt hatásának elemzése főkomponens-analízissel. Növénytermelés. 45. 6. 453-462.

Washington Wheat Facts 2015/2016; http://wagrains.org/wp-content/uploads/2015/04/WGC-201617WF4WebFinal.pdf

doi: 10.34116/NTI.2019.AA.18 